\title{
A cross-sectional analysis of acute hepatitis B virus reported to the Vancouver Coastal Health Authority from 2000 to 2003
}

\author{
Yvette Leung MD CCFP ${ }^{1}$, Jessica Ip Chan BSc CPHIC MBA ${ }^{2}$, Eric Yoshida MD MHSc FRCPC ${ }^{1}$, \\ Hong-Xing Wu MD PhD ${ }^{3}$, Patricia C Daly MD FRCPC ${ }^{2}$
}

\begin{abstract}
Y Leung, JI Chan, E Yoshida, H-X Wu, PC Daly. A crosssectional analysis of acute hepatitis $B$ virus reported to the Vancouver Coastal Health Authority from 2000 to 2003. Can J Gastroenterol 2006;20(7):471-474.
\end{abstract}

BACKGROUND: Acute hepatitis B virus (HBV) transmission remains a significant public health problem despite effective vaccination and prophylaxis strategies. Vancouver, British Columbia, has a large ethnic community from endemic areas, which may further impact on the epidemiology of acute HBV. A cross-sectional study of factors associated with acute HBV cases reported to the Vancouver Coastal Health Authority (Vancouver, British Columbia) from 2000 to 2003 is reported.

METHODS: New seropositive cases of hepatitis B surface antigen were reported to the Vancouver Coastal Health Authority Office of Communicable Disease Control. Patients meeting both clinical and laboratory criteria for acute HBV were interviewed by telephone for demographic and risk behaviour information. Risk behaviours within the last six months before disease onset were ranked on efficiency of transmission in a mutually exclusive risk category.

RESULTS: There were 78 patients of identified acute HBV in Vancouver from 2000 to 2003 . The overall incidence rate was 3.38 per 100,000 person years. Outside of Canada, Asia was the most common place of birth $(29.5 \%)$. The three most frequently identified risk factors were men who have sex with men (21.9\%), heterosexual activity with two or more partners (14.0\%) and intravenous drug use (14.0\%). Sexual contact with an HBV carrier was identified in $9.4 \%$ of patients.

CONCLUSIONS: Sexual transmission is a major mode in the spread of HBV in Vancouver. Existing public education, surveillance and vaccination strategies for HBV need to be strengthened to address those engaging in risky behaviours.

Key Words: Acute hepatitis B; Asia; Risk factors; Sexual transmission
Une analyse transversale des cas d'hépatite B aiguë déclarés aux autorités sanitaires côtières de Vancouver entre 2000 et 2003

HISTORIQUE : La transmission du virus de l'hépatite B (VHB) demeure un grave problème de santé publique malgré des stratégies de vaccination et de prophylaxie efficaces. La ville de Vancouver, en Colombie-Britannique est dotée d'une vaste communauté ethnique provenant de régions endémiques, ce qui peut avoir des répercussions plus importantes sur l'épidémiologie du VHB aigu. Une étude transversale des facteurs associés au VHB aigu déclarés aux autorités sanitaires côtières de Vancouver (Vancouver, Colombie-Britannique) entre 2000 et 2003 est divulguée.

MÉTHODOLOGIE : De nouveaux cas séropositifs à l'antigène de surface de l'hépatite B ont été déclarés au contrôle des maladies transmissibles des autorités sanitaires côtières de Vancouver. On a fait passer une entrevue téléphonique aux patients respectant à la fois les critères cliniques et de laboratoire du VHB aigu pour obtenir des renseignements démographiques et de l'information sur leurs comportements à risque. Les comportements à risque au cours des six mois précédant l'apparition de la maladie étaient classés selon l'efficacité de la transmission dans une catégorie de risque mutuellement exclusive.

RÉSULTATS : On a recensé 78 patients atteints d'un VHB aigu dépistés à Vancouver entre 2000 et 2003. Le taux d'incidence global était de 3,38 cas par 100000 personnes-année. À part le Canada, l'Asie était le principal lieu de naissance $(29,5 \%)$. Les trois facteurs de risque les plus fréquents étaient les relations sexuelles entre hommes (21,9\%), les activités hétérosexuelles avec au moins deux partenaires $(14,0 \%)$ et l'usage de drogues intraveineuses $(14,0 \%)$. Un contact sexuel avec un porteur du VHB était repéré chez 9,4\% des patients.

CONCLUSIONS : La transmission sexuelle est un mode important de propagation du VHB à Vancouver. L'éducation publique en place, la surveillance et les stratégies de vaccination relatives au VHB doivent être renforcées pour inclure les personnes qui adoptent des comportements à risque. 凹epatitis B virus (HBV) is well recognized to be a preventLable, communicable, infectious disease with both acute and chronic consequences. Acute disease ranges from asymptomatic infection, to mild illness, to fulminant liver failure. Those who fail to clear the virus could go on to develop chronic HBV with the potential for cirrhosis and hepatocellular carcinoma. Despite the availability of an effective vaccine and prophylaxis strategies following high-risk incidents, as well as ongoing public education regarding safe sexual practices, acute transmission remains a significant public health problem both internationally and in Canada. In this country, the estimated annual incidence rate of acute HBV is 2.3 per 100,000 person years (1). This, however, is likely an underestimate given that only patients with symptomatic disease come to the attention of their physicians and, in many cases, the disease may be unreported to the local public health office. The major risk

${ }^{1}$ Department of Medicine, University of British Columbia; ${ }^{2}$ Communicable Disease Control for the Vancouver Coastal Health Authority,

Vancouver, British Columbia; ${ }^{3}$ Blood Safety Surveillance and Health Care Acquired Infection Division, Centre for Infectious Disease

Prevention and Control, Public Health Agency of Canada, Ottawa, Ontario

Correspondence: Dr Eric M Yoshida, Vancouver General Hospital, Division of Gastroenterology, 100 - 2647 Willow Street, Vancouver,

British Columbia V5Z 3P1. Telephone 604-875-5371, fax 604-875-5447, e-mail eyoshida@interchange.ubc.ca

Received for publication May 5, 2005. Accepted January 13, 2006 


\section{TABLE 1}

Sex-specific frequency and rate per 100,000 person years of acute hepatitis $B$ virus patients by year and during the four-year surveillance period

\begin{tabular}{lccc}
\hline Year & $\begin{array}{c}\text { Women, } \\
\text { n (rate) }\end{array}$ & $\begin{array}{c}\text { Men, } \\
\text { n (rate) }\end{array}$ & $\begin{array}{c}\text { Total, } \\
\text { n (rate) }\end{array}$ \\
\hline 2000 & $4(1.39)$ & $20(7.06)$ & $24(4.20)$ \\
2001 & $1(0.34)$ & $16(5.57)$ & $17(2.93)$ \\
2002 & $3(1.03)$ & $15(5.23)$ & $18(3.11)$ \\
2003 & $3(1.03)$ & $16(5.59)$ & $19(3.29)$ \\
Total & $11(0.95)$ & $67(5.86)$ & $78(3.38)$ \\
\hline
\end{tabular}

factors associated with acute HBV infection in Canada have previously been reported to be injection drug use and high-risk sexual behaviour, such as multiple partners or sex with HBV carriers (1).

The prevalence of HBV in Canada is highly variable among subgroups of the population. There is a higher prevalence of hepatitis $\mathrm{B}$ surface antigen ( $\mathrm{HBs} \mathrm{Ag})$ in the immigrant population, $4.3 \%$ versus $0.2 \%$ to $0.5 \%$ in the nonimmigrant population (2). Given that Vancouver, British Columbia has a large immigrant population (3) from areas with a high endemic rate of chronic HBV $(4,5)$, the transmission pattern and demographics of acute HBV patients in Vancouver may differ from national trends. In Asia, a region with a high endemic rate of HBV, vertical transmission and horizontal transmission within household contacts are major risk factors for HBV infection $(6,7)$.

In the present study, the demographics and risk factors in newly identified acute HBV patients in the city of Vancouver were analyzed. We hypothesized that the transmission pattern and demographics of new patients in Vancouver may be influenced by the prevalence of chronic HBV carriers in this region and the city's unique demographic composition. We reviewed the data collected by the Office of Communicable Disease Control of the Vancouver Coastal Health Authority (Vancouver, British Columbia) surveillance program for newly identified HBV and hepatitis $\mathrm{C}$ virus (HCV) patients for the specific, contemporary time period from 2000 to 2003.

\section{METHODS}

Data were collected by the Vancouver Coastal Health Authority Office of Communicable Disease Control of all cases of acute HBV under the protocol of Health Canada's national enhanced surveillance for newly identified HBV and HCV patients. Newly identified HBsAg cases were reported by all commercial and public diagnostic medical laboratories to the Communicable Disease Control Office. To determine whether the patients were acute or chronic, a letter was sent to the physician who ordered the original HBV serology requesting clinical information and laboratory data about each patient. Community health clinics in the health region and the Sexually Transmitted Disease Clinic of the British Columbia Centre for Disease Control were also contacted for further information. Local physicians were informed of the enhanced surveillance at the start of the program. Patient interviews were conducted by telephone. Patients were informed as to how their risk factor information would be used and consent was sought for the sharing of the data. The collected data were entered into a database, where they were encrypted and transferred electronically to Health Canada to be incorporated into the national database.
TABLE 2

Age distribution of acute hepatitis $B$ virus patients during the four-year surveillance period

\begin{tabular}{lcc}
\hline Age (years) & Frequency, $\mathbf{n}$ & Per cent \\
\hline$<10$ & 0 & 0.0 \\
$10-19$ & 1 & 1.3 \\
$20-29$ & 17 & 21.8 \\
$30-39$ & 26 & 33.3 \\
$40-49$ & 23 & 29.5 \\
$50-59$ & 10 & 12.8 \\
$\geq 60$ & 1 & 1.3 \\
\hline
\end{tabular}

Acute HBV patients met both clinical and laboratory criteria. Clinical criteria was defined by an acute illness with the discrete onset of symptoms associated with hepatitis (malaise, nausea, fatigue, dark urine, loss of appetite and jaundice), and elevated serum aminotransferase levels. The laboratory criteria required serum aminotransferase levels that were at least 2.5 times the upper limit of normal, a negative hepatitis A immunoglobulin (Ig) $\mathrm{M}$ antibody test, and either a positive $\mathrm{HBs} \mathrm{Ag}$ test or a positive IgM antibody to the hepatitis B core antigen. An alternative laboratory definition was the seroconversion of either the $\mathrm{HBs} A g$ test or the IgM antibody to the hepatitis B core antigen from negative to positive within the past 12 months.

Risk behaviours within the six months before disease onset were ranked in a similiar order as the national surveillance study (1), which takes into consideration known data on efficiency of transmission (8-10). The risk behaviours were ranked in the following order: intravenous drug use, noninjection drug use (snorting or straw), blood transfusion, blood product recipient, sex with a HBV carrier, men who have sex with men (MSM), heterosexual activity with more than one partner, tattooing, piercing, acupuncture, occupational exposure to blood, HBV carrier in household, hemodialysis, perinatal exposure, incarceration, association with an institution for the developmentally delayed, hospitalization, tissue or organ transplant, surgery, dental surgery or unknown. If a patient had more than one identified risk behaviour in the six months before disease onset, the patient was assigned to the highest ranked risk behaviour.

\section{RESULTS}

In the Vancouver Coastal Health Region, over a four-year period, there were 78 newly identified patients with acute HBV from April 1, 2000, to March 31, 2004. The incidence rates for 2000, 2001, 2002 and 2003, respectively, per 100,000 person years, were $4.20,2.93,3.11$ and 3.29. Men accounted for 67 of 78 patients $(86 \%)$, and women 11 of 78 patients $(14 \%)$ over the four-year period. Table 1 lists the frequency of men versus women with acute HBV as well as sexspecific and total incidence rate per 100,000 person years categorized by surveillance year. The overall incidence rate was 3.38 per 100,00 person years over the surveillance period in the Vancouver region. The age distribution is shown in Table 2. The majority of the patients clustered between 20 and 49 years of age.

The most frequently identified place of birth was Canada (32 of 78 [41\%]), followed by Asia (23 of 78 [29.5\%]) (Table 3). Place of birth was unknown for 16 patients $(21 \%)$. Ethnic group is shown in Table 4. The most frequently identified ethnicity was Caucasian (39 of 78 patients [50\%]). The second most frequently identified ethnicity was 
TABLE 3

Birthplace of acute hepatitis $B$ virus patients during the four-year surveillance period

\begin{tabular}{lcc}
\hline Birthplace & Frequency, $\mathbf{n}$ & Per cent \\
\hline Canada & 32 & 41.0 \\
Asia & 23 & 29.5 \\
United States & 2 & 2.6 \\
United Kingdom & 1 & 1.3 \\
Chile & 1 & 1.3 \\
Mexico & 2 & 2.6 \\
Costa Rica & 1 & 1.3 \\
Unknown & 16 & 20.5 \\
\hline
\end{tabular}

\section{TABLE 4}

Ethnic group of acute hepatitis $B$ virus patients during the four-year surveillance period

\begin{tabular}{lcc}
\hline Ethnic group & Frequency, $\mathbf{n}$ & Per cent \\
\hline Caucasian & 39 & 50.0 \\
Asian/South Asian/Indian & 23 & 29.5 \\
First Nations & 1 & 1.3 \\
African-Canadian & 1 & 1.3 \\
Unknown & 14 & 17.9
\end{tabular}

Asian/South Asian/Indian (23 of 78 [29.5\%]). Racial group was unknown for 14 patients (17.9\%).

Risk factor information was available for 64 patients (82\%), because 14 patients were not interviewed (11 refused, two died for reasons not related to hepatitis and one unknown reason). In cases where more than one risk exposure was reported, the hierarchical system for coding was used (Table 5). Sexual activity involving MSM was the most frequently identified risk behaviour (14 patients [21.9\%]). Heterosexual activity with greater than one sexual partner and intravenous drug use both involved nine patients, respectively, (14\%). There were six cases of sexual contact with an HBV carrier (9.4\%). In total, 29 of $64(45.3 \%)$ patients identified sexual contact as their risk behaviour. Of nine patients who used intravenous drugs, five shared needles. Four patients used noninjection drugs in the form of snorting or straw use. Ten of 64 interviewed patients did not have any identifiable risk factor (15.6\%). Of 64 interviewed patients, none had a history of immunization for HBV.

\section{DISCUSSION}

The incidence of newly identified acute HBV patients in Vancouver over a four-year period is 3.38 patients per 100,000 person years. This is higher than the reported rates from the national data of 2.3 per 100,000 person years (1).

The three most frequently identified risk factors were MSM (21.9\%), heterosexual activity with two or more partners $(14.0 \%)$ and intravenous drug use (14.0\%). Our data are consistent with other Canadian data as well as trends in other developed countries $(1,11-16)$ which show that sexual transmission plays a major mode in the spread of HBV. Although this is not a new finding, given the availability of effective vaccination, prophylaxis following high-risk behaviour and previous public education campaigns regarding 'safe sex', this is still a disturbing finding. This finding strongly suggests that continued, and perhaps even increased, public education, and awareness of this perpetual public health risk, is still needed in the 21 st century.
TABLE 5

Risk behaviours reported by interviewed acute hepatitis $B$ virus patients during the four-year surveillance period $(n=64)$

\begin{tabular}{lcc}
\hline Risk behaviour & Frequency, $\mathbf{n}$ & Per cent \\
\hline Intravenous drug use & 9 & 14.0 \\
Noninjection drug use & 4 & 6.2 \\
Blood transfusion & 0 & 0.0 \\
Blood product & 0 & 0.0 \\
Sex with hepatitis B virus carrier & 6 & 9.4 \\
Men who have sex with men & 14 & 21.9 \\
Heterosexual activity (more than & 9 & 14.0 \\
$\quad$ one sexual partner) & & \\
Tattooing & 0 & 0.0 \\
Body piercing & 0 & 0.0 \\
Acupuncture & 4 & 6.2 \\
Occupational exposure to blood & 1 & 1.6 \\
Hepatitis B virus carrier in the & 1 & 1.6 \\
$\quad$ household & & \\
Hemodialysis & 0 & 0.0 \\
Perinatal exposure & 0 & 0.0 \\
Incarceration & 0 & 0.0 \\
Institution-associated & 0 & 0.0 \\
Hospitalization & 0 & 0.0 \\
Tissue/organ transplant & 0 & 0.0 \\
Surgery & 1 & 1.6 \\
Dental surgery & 5 & 7.8 \\
No identifiable risk factor & 10 & 15.6 \\
\hline
\end{tabular}

The Asia-Pacific community of Vancouver is, by proportional size, the largest of any city in Canada. The most recent Canadian census (3) reported that this community constituted $25 \%$ of the city's population compared with only $14 \%$ in Toronto and 3\% in Montreal. We hypothesized that the transmission pattern and demographics of new cases in Vancouver may be influenced by the estimated high prevalence of chronic HBV carriers who may reside in this community. Only one of our patients reported a HBV carrier in their household and sexual contact with a HBV carrier was reported by six patients $(9.4 \%)$. This is similiar to the findings by Zou et al (1) who found $8.9 \%$ of patients had sex with HBV carriers when they looked at acute HBV in four health regions across Canada during one year. We do note, however, that in our analysis, almost $30 \%$ of new patients were from Asia, suggesting that a high prevalence of carriers within this community may lead to new acute cases among previous noninfected individuals within the community. Given that immigrants from this area may not have received vaccination, and our own recent findings that younger members of this community may have a suboptimal awareness of HBV (17), this may be a community for whom public education is needed.

Another interesting finding was that our data show a higher percentage of cases in Vancouver of MSM as a risk behaviour (21.9\% versus $5.4 \%$ in the national data) (1). Given that this community has historically been targeted for public health campaigns with regard to safe sexual practices, this finding is also discomforting and suggests that public education needs to be an ongoing concern.

Another interesting trend was the apparent decrease in injection drug use as a risk behaviour for acute HBV. Zou et al (1) found $25 \%$ of their patients reported injection drug use, in 
contrast with $14 \%$ in the present study. This is particularly interesting given Vancouver's large intravenous drug user population and the fact that $\mathrm{HCV}$ is widespread in this population, with a reported incidence of 29.1 per 100 person years in Vancouver's downtown eastside area $(18,19)$. Although differences may be accounted for by the increase in education of the intravenous drug user population between 1998 and 1999, and our present cohort between 2000 and 2003, this is probably unlikely. A more likely reason is that a significant proportion of those at risk may have already had past exposure to HBV (20), had undergone HBV vaccination or are unreported.

An important finding of the present study was that none of the 64 interviewed patients had a history of immunization for HBV. Although universal immunization of school age children in Canada has been implemented since the early 1990s, we note that this policy missed the high-risk groups in our study.

\section{REFERENCES}

1. Zou S, Zhang J, Tepper M, et al. Enhanced surveillance of acute hepatitis B and C in four health regions in Canada, 1998 to 1999. Can J Infect Dis Med Microbiol 2001;12:357-63.

2. Canadian Association for the Study of the Liver consensus conference rapporteur group. The Canadian consensus conference on the management of viral hepatitis. <http:/www.lhsc.on.ca/casl/cont.htm> (Version current at January 16, 2006).

3. Statistics Canada. Immigration population by place of birth, by census metropolitan areas (2001 Census).

$<$ http://www.statcan.ca/english/Pgdb/demo35e.htm>

(Version current at January 16, 2006).

4. Maynard JE. Hepatitis B: Global importance and need for control. Vaccine 1990;8:S18-20.

5. Gust ID. Epidemiology of hepatitis B infection in the Western Pacific and South East Asia. Gut 1996;38(Suppl 2):S18-23.

6. Yao GB. Importance of perinatal versus horizontal transmission of hepatitis B virus infection in China. Gut 1996;38(Suppl 2):S39-42.

7. Nguyen MH, Keeffe EB. Chronic hepatitis B and hepatitis C in Asian Americans. Rev Gastroenterol Disord 2003;3:125-34.

8. Remis RS, Dufour A, Alary M, et al. Association of hepatitis B virus infection with other sexually transmitted infections in homosexual men. Omega Study Group. Am J Public Health 2000;90:1570-4.

9. Alter MJ. Epidemiology and prevention of hepatitis B. Semin Liver Dis 2003;23:39-46.

10. Custer B, Sullivan SD, Hazlet TK, Iloeje U, Veenstra DL, Kowdley KV. Global epidemiology of hepatitis B virus. J Clin Gastroenterol 2004;38:S158-68.

11. Romanowski B, Campbell P. Sero-epidemiologic study to determine the prevalence and risk of hepatitis B in a Canadian
Most of our patients were older than 20 years of age and therefore were not part of the cohort of childhood universal vaccination. Furthermore, less than one-half of our patients were born in Canada. Currently, the public health policy is to provide free vaccinations in the Vancouver health region for sexually active MSM, sexual partners of HBV carriers and intravenous drug users. However, there were an equal number of patients involved in heterosexual activity with more than one partner within six months and intravenous drug use. Strategies for public education and vaccination for HBV need to be strengthened to reach older adults who engage in sexual behaviour that have been associated with risk of transmission of HBV regardless of whether it is MSM or multiple heterosexual partners. Public education and surveillance will also be necessary in communities, such as the Asia-Pacific community, that can be expected to have a high number of chronic carriers.

heterosexual sexually transmitted disease population. Can J Public Health 1994;85:205-7.

12. Brook MG. Sexually acquired hepatitis. Sex Transm Infect 2002;78:235-40.

13. Balogun MA, Ramsay ME, Fairley CK, Collins M, Heptonstall J. Acute hepatitis B infection in England and Wales: 1985-96. Epidemiol Infect 1999;122:125-31.

14. Goldstein ST, Alter MJ, Williams IT, et al. Incidence and risk factors for acute hepatitis B in the United States, 1982-1988: Implications for vaccination programs. J Infect Dis 2002;185:713-9.

15. Arima S, Michitaka K, Horiike N, et al. Change of acute hepatitis B transmission routes in Japan. J Gastroenterol 2003;38:772-5

16. Trepka MJ, Weisbord JS, Zhang G, Brewer T. Hepatitis B virus infection risk factors and immunity among sexually transmitted disease clinic clients. Sex Transm Dis 2003;30:914-8.

17. Cheung J, Lee TK, Teh C-Z, Wang CYM, Kwan WCP, Yoshida EM. Cross-sectional study of hepatitis B awareness among Chinese and Southeast Asian Canadians in the VancouverRichmond community. Can J Gastroenterol 2005;19:245-9.

18. Patrick DM, Tyndall MW, Cornelisse PG, et al. Incidence of hepatitis $\mathrm{C}$ virus infection among injection drug users during an outbreak of HIV infection. CMAJ 2001;165:889-95.

19. Anand CM, Fonseca K, Walle RP, Powell S, Williams M. Antibody to hepatitis $\mathrm{C}$ virus in selected groups of a Canadian urban population. Int J Epidemiol 1992;21:142-5.

20. Moses S, Mestery K, Kaita KD, Minuk GY. Viral hepatitis in a Canadian street-involved population. Can J Public Health 2002;93:123-8. 


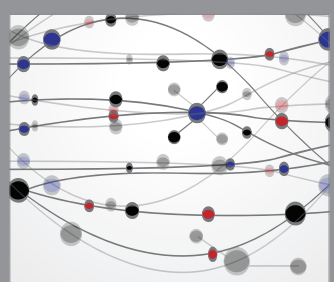

The Scientific World Journal
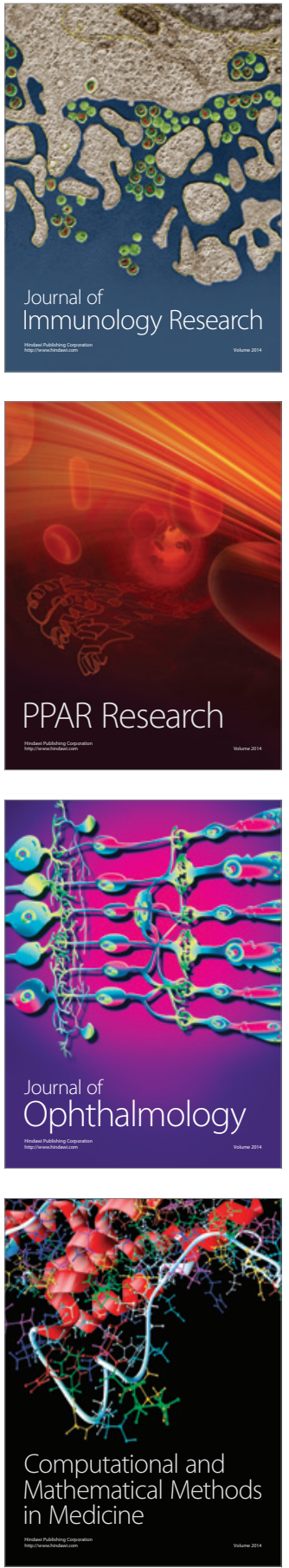

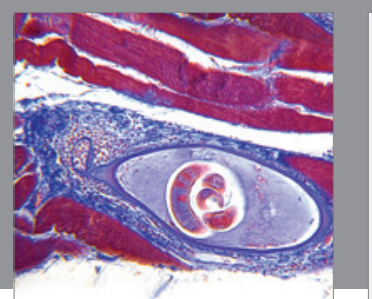

Gastroenterology Research and Practice

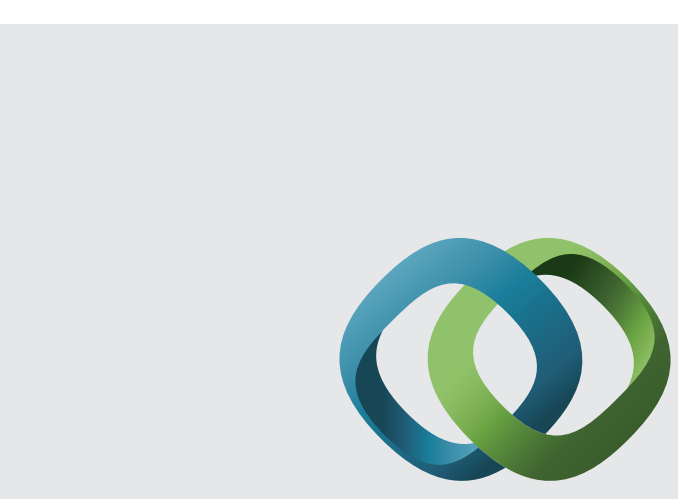

\section{Hindawi}

Submit your manuscripts at

http://www.hindawi.com
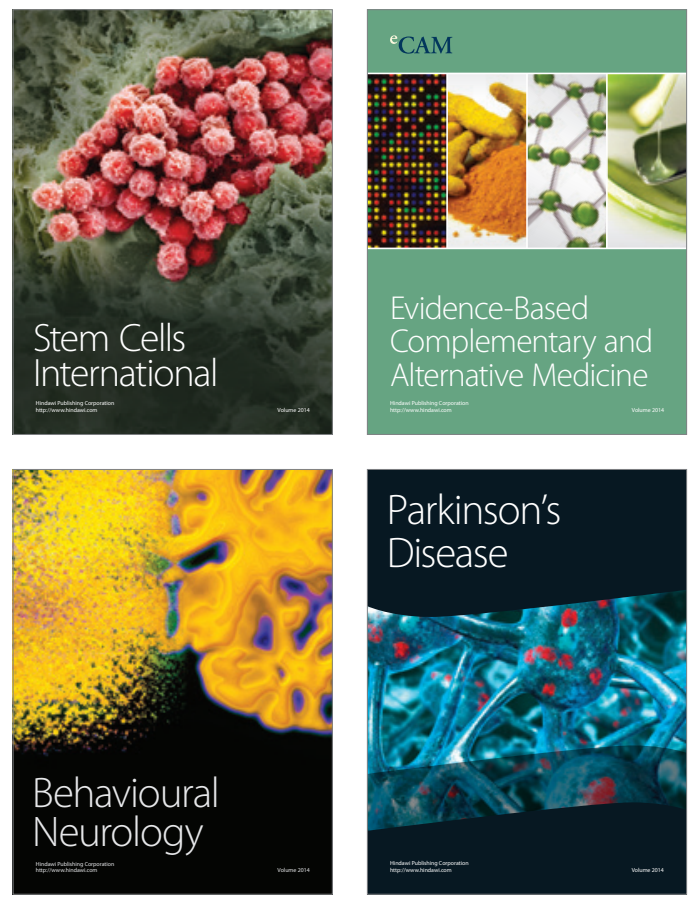
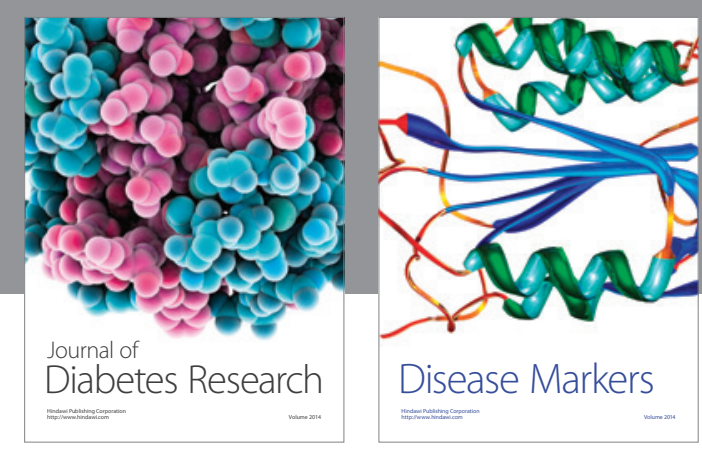

Disease Markers
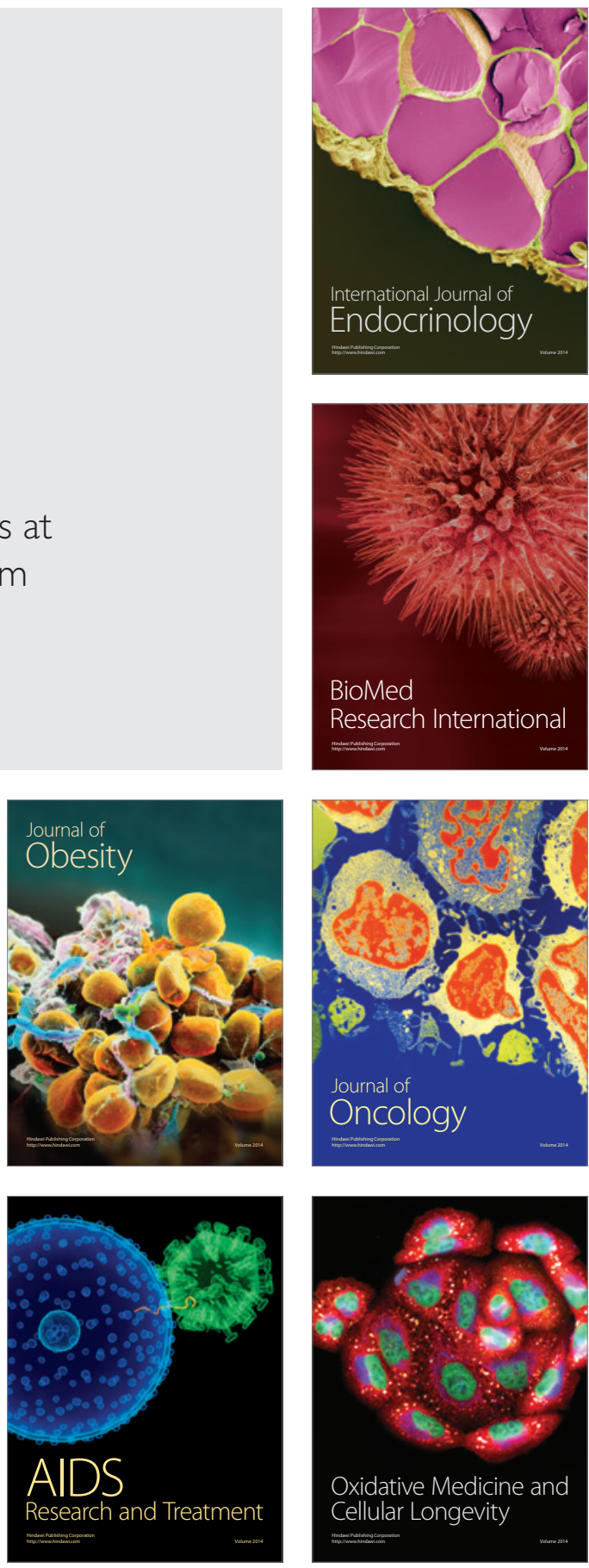